https://helda.helsinki.fi

\title{
Affective Labor and Feminist Politics
}

\section{Oksala, Johanna}

2016

Oksala , J 2016 , ' Affective Labor and Feminist Politics ', Signs , vol. 41 , no. 2 , pp. 281-303 . https://doi.org/10.1086/682920

http://hdl.handle.net/10138/228365

https://doi.org/10.1086/682920

Downloaded from Helda, University of Helsinki institutional repository.

This is an electronic reprint of the original article.

This reprint may differ from the original in pagination and typographic detail.

Please cite the original version. 


\section{Affective Labor and Feminist Politics}

Capitalism has made, and continues to make money out of our cooking, smiling, fucking.

- Silvia Federici $(2012,19)$.

$\mathrm{T}$

he global rise of neoliberalism as the leading political and economic paradigm and its detrimental effects on both women and feminist politics has prompted many feminist theorists to argue that feminism must now turn away from poststructuralism and back toward a Marxist analysis of global capitalism. ${ }^{1}$ A return to Marxist feminism is not as easy it might seem, however. Many of the premises on which Marxist-feminist theory was built in the 1970s appear highly problematic or even outdated today. Women's role in the labor market has changed dramatically; for example, the "feminization of labor" has become a sociological catchphrase. ${ }^{2}$ This widely used but ambiguous notion denotes not only the quantitative increase of women in the labor market globally - the growth of the service industries and the way women have been progressively transformed into a strategic pool of labor. It also denotes a qualitative change in the nature of labor: the characteristics historically present in female work-precariousness, flexibility, mobility, fragmentary nature, low status, and low pay-have increasingly come to characterize most of the work in global capitalism. Hence, the iconic figures of the male proletarian and the housewife do not seem to adequately represent the gendered spheres of advanced capitalist production and reproduction any longer.

Simply discarding poststructuralist insights in feminist theory does not seem feasible either. The early Marxist-feminist attempts to model gender oppression on the model of class oppression proved problematic: men did not oppress women as a class. The persistent Foucauldian critique of traditional forms of Marxist theory has targeted the latter's inability to account for a microphysics of power-for the different ways in which subjects

\footnotetext{
${ }^{1}$ See, e.g., Mies (1998, xiv-xviii) and Eisenstein (2009, 212-13).

${ }^{2}$ For different definitions of the concept of feminization of labor, see, e.g., Morini (2007, 41-44).
}

[Signs: Journal of Women in Culture and Society 2016, vol. 41, no. 2]

(c) 2015 by The University of Chicago. All rights reserved. 0097-9740/2016/4102-0002\$10.00 
are constituted in intersecting, capillary networks of power. ${ }^{3}$ While effectively exposing forms of exploitation and alienation, Marxist theory has tended to conceive of power relations in terms of class antagonism between capital and the proletariat.

Contemporary Marxist-feminist thinkers have therefore increasingly turned to neo-Marxist approaches, such as Michael Hardt's and Antonio Negri's writings. In their highly influential trilogy, Empire (2000), Multitude (2004), and Commonwealth (2009), Hardt and Negri bring together poststructuralist and Marxist frameworks in order to account for the changes in advanced capitalist production, laboring processes, and contemporary forms of the subject. Kathi Weeks' recent book The Problem with Work: Feminism, Marxism, Antiwork Politics, and Postwork Imaginaries (2011), for example, is an important feminist appropriation of Hardt and Negri's conceptual framework. Weeks adopts their key arguments about the profound changes that capitalist production has undergone in the last decades and attempts to draw the consequences of these changes for feminist theory and particularly for our concept of work. She wants to add to the critique of exploitative and alienating dimensions of work "a focus on its political relations of power" $(2011,21)$.

I am sympathetic to the attempts to combine Marxist and poststructuralist frameworks, and I fully agree with Weeks and other Marxist feminists that a critical analysis of contemporary capitalism is a pressing task for feminist theory today. The rapid economic globalization characterizing the last thirty or forty years has put women and feminist thinking in a completely new political situation, and one of the key issues that it forces us to reassess is the nature of work and its role in feminist politics. ${ }^{4}$ It is my contention that the feminist attempt to address this issue by turning to Hardt's and Negri's theories is highly problematic, however.

\footnotetext{
${ }^{3}$ It can be argued that Karl Marx recognized implicitly the idea of that power relations are constitutive of subjects in his analysis of the transition from formal subsumption to the real subsumption of labor. See, e.g., Hardt and Negri $(2000,25)$. By the real subsumption of labor, Marx referred to the way in which capital not only takes over and manages an already existing labor process but completely transforms its nature and, by extension, the laborers themselves. See Marx ([1867] 1976, 645, 1019-38). However, in many appropriations of Marx this idea is underdeveloped, giving way to the idea that the proletariat occupies a specific position in the relations of production that allows it to view social reality from a privileged, revolutionary perspective. See, e.g., Lukács (1971).

${ }^{4}$ Work has traditionally been understood as an important occasion for the emancipation of women from male oppression. Economic independence and self-determination have been seen as the keys to women's empowerment, and both liberal and socialist feminists have advocated women's right to equal work.
} 
My critical analysis here focuses on the political potential of their influential notion of affective labor. Affective labor plays a crucial role in Hardt and Negri's analysis of contemporary capitalism, but it also brings to fore the key issues that are at stake in the feminist critiques of capitalism.

My argument proceeds in two stages. I begin by briefly explicating Hardt and Negri's concept of affective labor and outline what I see as its potential benefits for advancing critical feminist thought and political imagination. In the second part of the article I turn to a critical evaluation of the notion in connection with feminist politics. While I acknowledge the strengths of this framework in characterizing contemporary laboring practices, I nonetheless want to expose its shortcomings in advancing feminist politics. I contend that in order to imagine effective political responses to the problems currently facing us, feminist politics needs theoretical distinctions within the category of affective labor that allow us to advance a normative-political and ethical-problematization of our current forms of work.

\section{Affective labor}

Hardt and Negri's well-known claim is that there has been a shift from an industrial paradigm in which industry and the manufacture of durable goods formed the dominant sector of the economy to a paradigm prevailing today in which the production of services and the manipulation of information dominates. This passage toward an "informational economy" has necessarily brought about a radical change in the quality of labor and in the nature of laboring processes $(2000,289)$. Information, communication, knowledge, affects, and relationships have come to play a foundational role in the production process. Since the production of services results in no material and durable goods, Hardt and Negri define the labor involved in this production as immaterial labor $(2000,290) .^{5}$ Their key argument is that it is the paradigmatic form of labor today-not quantitatively the most common but a hegemonic model toward which all forms of work are tending. ${ }^{6}$

\footnotetext{
5 The labor involved in all immaterial productions remains material in the sense that it involves bodies and brain. Its products are immaterial, however. See, e.g., Hardt and Negri $(2004,109)$.

${ }^{6}$ Hardt and Negri's argument is not that most of the workers in the world are producing primarily immaterial goods. This would be clearly false: immaterial labor constitutes a minority of global labor, and it is concentrated in some of the dominant regions of the globe. Their claim is rather that immaterial labor has become hegemonic in qualitative terms and
} 
Affective labor is theorized as an important subcategory of immaterial labor. ${ }^{7}$ It is the labor of human contact and interaction, which involves the production and manipulation of affects. Its "products" are relationships and emotional responses: "a feeling of ease, well-being, satisfaction, excitement or passion" (Hardt and Negri 2004, 96). Affective labor is thus immaterial in the sense that its products are intangible, even though it is usually corporeal and mixes with material forms of labor. ${ }^{8}$

The idea of affective labor appears to have at least three crucial advantages in terms of feminist theory and politics. First, it identifies and recognizes an important contemporary form of labor most often performed by women. The affective labor of human contact and interaction forms an essential component of almost all work today. Characteristics such as emotional resources and communicative skills have become increasingly important. Workers are expected to mobilize emotional and social skills for professional goals, resulting in the blending of the private and the public, the informal and the formal, skills and resources. ${ }^{9}$ The potential domains of affective labor are also rapidly expanding beyond what anyone could imagine a couple of decades ago, creating businesses such as breast feeding consultants and wedding planners. As the marketization and commodification of everyday life expands, people have increasingly come to rely on the affective services that they buy and that they used to receive from their families and communities - whether in health care, child care, entertainment, dating, and so on. Affective labor is increasingly outsourced, and the domestic, private realm is marketized. ${ }^{10}$

has imposed a tendency on other forms of labor and society itself. Immaterial labor is today in the same position that industrial labor was 150 years ago, when it accounted for only a small fraction of global production and was concentrated in a small part of the world but nonetheless exerted hegemony over all other forms of production. Just as in that phase all forms of labor and society itself had to industrialize, today labor and society have to become intelligent, communicative, and affective (Hardt and Negri 2004, 109).

${ }^{7}$ Hardt and Negri distinguish three types of immaterial labor that drive the service sector. The first is involved in industrial production, which has incorporated communication technologies in a way that transforms the production process itself. Manufacturing can be regarded as a service, and the material labor of the production of durable goods mixes with and tends toward immaterial labor. The second is the immaterial labor of analytical and symbolic tasks, which divides into creative and intelligent manipulation on the one hand and routine symbolic tasks on the other. Finally, a third type of immaterial labor, affective labor, involves the production and manipulation of affects (Hardt and Negri 2000, 293).

${ }^{8}$ Hardt and Negri note how health care workers, for example, perform affective, cognitive, and linguistic tasks together with material ones, such as cleaning bedpans and changing bandages (2000, 108-9).

9 See, e.g., Honneth and Hartmann $(2006,50)$.

${ }^{10}$ See, e.g., Hochschild (2013). 
While most feminist critiques of Hardt's and Negri's writings have focused on their omission of gender analysis, Hardt and Negri explicitly recognize the pioneering feminist work done on affective labor. ${ }^{11}$ They write that it is best understood "by beginning from what feminist analyses of 'women's work' have called 'labor in the bodily mode'" $(2000,293)$. Domestic labor is a paradigmatic example of affective labor for them: it requires repetitive material tasks such as cleaning and cooking, but it also involves producing affects, relationships, and forms of communication and cooperation among children, in the family, and in the community (2004, $110)$.

In the most recent volume of their trilogy, Commonwealth, they also acknowledge that affective labor is disproportionately required of women, both at work and at home. "In fact any woman who is not willing to do affective labor on call—smile appropriately, tend to hurt feelings, knit social relationships, and generally perform care and nurturing-is viewed as a kind of monster. Despite their massive entry into the wage labor force, furthermore, women are still primarily responsible in countries throughout the world for unpaid domestic and reproductive labor. . . . Women's double workday is a powerful obstacle to greater education and access to better and better-paid work" $(2009,134)$.

While highlighting women's care work and emotional labor, the second benefit of the notion of affective labor is that it does not rely on naturalized gender dualism or reified gender identities. Affective labor is gendered-it is in an important sense feminized labor-but it is important to acknowledge that is not performed exclusively by women. As Weeks (2007, 238-39) writes, "the practice of affective labor and presumably the potential political subjects that can be constituted on its basis cuts across the older binary divisions of both space and gender. Women and men are indeed still often engaged in different laboring practices, but these differences cannot be mapped onto a binary schema secured by recourse to a model of separate spheres." To assume the persistence of a gender division of work in our contemporary context in which the binary of men's and women's work has become increasingly unstable would be both theoretically and politically debilitating.

Third, the notion of affective labor is an important intervention in the Marxist debates on the role of domestic and reproductive labor in capitalism. The so-called domestic labor debates were a prolonged controversy in socialist feminism in the 1970s over the value and role of domestic

\footnotetext{
${ }^{11}$ See, e.g., Quinby (2004).
} 
work in capitalist production. ${ }^{12}$ This debate was mainly centered on the question of whether domestic labor was productive or unproductive labor and consequently, whether it was integral for capitalist production or not. Productive, as opposed to unproductive labor, as Karl Marx argues in Capital, is labor that creates surplus value directly, and it is therefore usually understood to comprise only certain forms of waged labor. ${ }^{13}$ The traditional Marxist position, including that of most Marxist feminists, was that domestic labor was unproductive labor. ${ }^{14}$ Although women at home performed services and produced things - cooked food, cleaned the house, cared for children, and so on-the products and services that resulted from their work were consumed directly and were not exchanged in the market. In Marxist terms, these products and services had use value but no exchange value.

Hardt's and Negri's radical intervention in this debate is to deny the distinctions between unproductive and productive labor, as well as between material production and social reproduction. According to Hardt and Negri, productive labor "cannot be limited to waged labor, but must refer to human creative capacities in all their generality" $(2000,105)$. In the period of industrial capitalism it seemed as if only the labor of waged workers was productive, and all other types of labor, such as domestic labor performed by women at home, appeared as merely reproductive or even unproductive. Their claim is that in the context of contemporary capitalism, however, in which the production of capital converges with the production and reproduction of social life itself, it becomes impossible to maintain the distinctions among productive, reproductive, and unproductive labor. All forms of labor today must be recognized as socially productive and understood as part of biopolitical production. In other words, all labor produces and reproduces social life, and in the process is exploited by capital.

When social production is understood in this broad sense, the unemployed and the housewives are no longer excluded from production, nor, consequently, from the proletariat or the multitude. Because all the different segments of society produce in common, they share a common potential to resist the domination of capital (Hardt and Negri 2004, 106-7). "This wide landscape of biopolitical production allows us finally to rec-

${ }^{12}$ For an account of the domestic labor debates, see, e.g., Vogel (1983, 13-28).

${ }^{13}$ See, e.g., Marx ([1867] 1976, 644, 1039-49).

${ }^{14}$ This view has been expounded by various Marxist thinkers, from Friedrich Engels to Juliet Mitchell. The traditional Marxist view was that women's oppression was essentially caused by their exclusion from worker-capitalist relations. See Engels ([1884] 1972) and Mitchell (1971). 
ognize the full generality of the concept of proletariat" and "the progressive indistinction between production and reproduction (Hardt and $\mathrm{Ne}$ gri 2000, 402). The upshot for feminist politics appears to be that women's affective labor is finally recognized as being directly productive of social reality, and that all women, not only working women, are recognized as important agents in the struggle against capitalism since they too belong to the proletariat or the multitude.

This idea is crucial to Kathi Weeks' feminist appropriation of Hardt and Negri. Weeks follows Hardt and Negri in arguing that in today's advanced capitalism, production and reproduction are thoroughly integrated, and that this situation forces feminist politics on a new footing. The traditional Marxist feminist category of reproductive labor used to include only the forms of unwaged work through which individuals meet their daily needs for food, shelter, and care, and raise a new generation to take their place. Today social reproduction must be understood in a much broader sense than reproductive or domestic labor. It denotes the production of all the forms of social cooperation on which capitalist accumulation depends as capital continually seeks to harness all of life to "its times, spaces, rhythms, purposes, and values" $(2011,29)$.

Weeks argues that the most compelling contributions to the domestic labor debate, therefore, were those unorthodox arguments that disregarded the division between productive and unproductive labor in arguing that women's domestic labor had to be understood as productive labor too $(2011,140)$. She refers to the Marxist feminists influenced by the Italian operaista movement, such as Silvia Federici and Mariarosa Dalla Costa. ${ }^{15}$ According to Weeks (2007), the failure of these early Marxist-feminist accounts nevertheless consisted of ultimately settling for a too-narrow concept of affective labor: in their accounts affective labor was still equated strictly with unwaged housework and domestic labor, and it was confined to the space of the household. A contemporary analysis of affective labor makes clear that such a narrow concept no longer suffices. Commodities are increasingly replacing domestically produced goods and services, and forms of caring and household work are transformed into feminized, racialized, and globalized forms of labor in the service sector $(2007$,

${ }^{15}$ See Dalla Costa and James (1973) and Federici (2012). Marxist-feminist thinkers also problematized the question of how the contribution made by domestic labor was determinate of the exchange value of labor power. In Marx's theory the value of labor power is determined by the value of commodities necessary for its reproduction. However, it is not clear in Marx's work whether this value covers individual workers or the entire household supported by the worker. If it covers the entire household, then the value of the domestic work must factor directly into the value of labor power. See Vogel $(1983,23)$. 
235-36). Weeks argues that feminist politics today must proceed from a theoretical recognition of this situation. She urges feminists to adopt a broader concept of social reproduction and to join forces with other radical proposals for a postwork society.

To sum up this section, the notion of affective labor appears to offer several benefits for feminist theory and politics. It is a much broader concept than the notion of domestic labor, for example, and is therefore able to elucidate in a novel way contemporary laboring practices. It is inclusive of women's labor and gives feminist concerns a central role in critical Marxist theory while at the same time troubling any stable distinction between two radically distinct gendered spheres of labor, women's unproductive and reproductive labor in the domestic realm and men's productive labor in the public sphere. It cuts across such dualisms as mind/body, public/private, and economy/culture. It thereby bridges the gap between a purely economic understanding and a broader sociopolitical understanding of capitalism. All this sounds promising. So what are my reservations about feminists embracing this notion?

\section{Anticapitalist feminist politics}

Hardt and Negri borrow the concept of biopolitics from Michel Foucault, but this notion becomes radically transformed into the notion of biopolitical production. Instead of designating distinct governmental technologies centered on the optimization and regulation of life, the term comes to designate the whole of the ontological process by which social reality is materially produced. Biopolitical production is thus not limited to economic phenomena but involves all aspects of social life, including networks of communication and information, linguistic forms, the production of knowledge, collaborative social relationships, affects, and the producers themselves: "The great industrial and financial powers thus produce not only commodities but also subjectivities. They produce agentic subjectivities within the biopolitical context: they produce needs, social relations, bodies and minds - which is to say, they produce producers" $(2000,32)$.

Through the idea of biopolitical production, Hard and Negri thus import into Marxist theory their own version of Foucault's idea of productive power. The way that Hardt and Negri understand subjectivation differs radically from Foucault, however. They understand it according to an economic model of production: in the quotation above, the way power produces subjects appears essentially no different from the process through which commodities are produced. In contrast, Foucault argues against economism in analyses of power, against the idea that we can analyze power 
relations according to economic models. ${ }^{16}$ His idea of productive power should not be understood as a straightforward empirical claim about disciplinary practices and institutions directly producing the people involved in them. Rather, power relations form the historical conditions of possibility for the production of true discourses, which form the matrix of intelligibility for identities and normalized subjectivities.

Foucault's claim that there is no outside to power relations also morphs in Hardt's and Negri's writings into the claim that there is no outside to the process of capitalist production. "Production becomes indististinguishable from reproduction," "subjects are at the same time producers and products of this unitary machine," and it is "no longer possible to identify a sign, a subject, a value, or a practice that is 'outside"' $(2000,385)$. While such a comprehensive understanding of capitalism as a sphere of biopolitical production with no outside seems to have radical political potential in breaking with narrow economism and in bringing together all kinds of seemingly separate struggles as struggles against capitalism-feminist, indigenous, and ecological struggles as well as various democratic strugglessuch an extensive understanding in fact turns out to be politically debilitating. It makes resistance against capitalism hard to imagine because it obfuscates the fact that capitalist societies, and our daily lives in them, are organized through various competing and divergent normativities, which are in constant struggle and tension with one another. While the normativity specific to capitalist economic production promotes such objectives and values as economic growth, efficiency, free competition, and equal exchange, for example, we are also daily engaged in social practices and human relationships that are based on very different normativities that would make no sense if assessed strictly economically.

This normative heterogeneity of capitalist societies implies that the political struggles against capitalism, and its narrow economic rationality, do not have to emerge from some pure outside. These struggles can draw from and build on the existing, alternative normativities embedded in the myriad social practices around us. They can take the form of organized activities that pit alternative values such as care, solidarity, and justice against economic efficiency and profit making, for example. However, in order to do that, we have to be able to identify and theorize the specificity of capitalism. Rather than being coextensive with life, it must be viewed as a historically specific socioeconomic system of production characterized by a particular and essentially restrictive normativity.

${ }^{16}$ See, e.g., Foucault $(2003,13)$. 
The idea of biopolitical production also radically transforms Marx's theory by eradicating his distinction between production and reproduction. Although a key tenet of Marx's theory is the idea that in capitalism labor power is a commodity that is exchanged in the market, it is understood as a special kind of commodity, not only because it is capable of producing surplus value but also because it is produced in an essentially different way than other commodities. With the idea of biopolitical production these insights are lost because capitalism is understood not as a distinctive form of economic production but as a comprehensive social formation. ${ }^{17}$ The relations of production and the relations constitutive of the producers themselves become superimposed.

It is my contention that despite the pressing need to reconfigure traditional categories of labor in today's society, it is nevertheless crucial for both feminist theory and politics to maintain the ability to make sharp distinctions between the different types of labor that affective labor comprises. Affective labor not only identifies qualitative changes in today's waged work but also, inadvertently, eradicates the differences between such varied laborers as child bearers, child rearers, hospitality industry workers, wedding planners, and Walmart greeters. Affective labor includes at least four different kinds of labor that traditional Marxist analyses have sharply distinguished with the help of the distinctions between productive and unproductive labor and production and reproduction. Let me first briefly clarify these different types before I proceed with the argument.

First, affective labor denotes care work that is not commodified, such as child rearing at home or looking after sick or elderly members of the family. In other words, it is what traditional Marxist feminist analysis understands as reproductive labor as opposed to productive labor. Second, affective labor can also be care work or reproductive labor that is commodified and as such productive labor. Examples of such affective labor would include, for example, day care providers, workers in private nursing homes, or as an extreme case, surrogate pregnancy that is commercialized. Third and fourth, affective labor denotes waged and unwaged labor that does not directly reproduce labor power but instead aims at producing affects. When it is waged labor, its principal objective is usually to realize a profit for a specific company, not to reproduce workers. Such affective labor normally requires face-to-face or voice-to-voice contact with the public. A paradigmatic example is flight attendants: their work requires

\footnotetext{
${ }^{17}$ In the autonomist Marxist tradition the notion of social factory refers to the idea that capitalist relations cannot be confined within the factory walls but permeate the whole society. See Tronti (1966).
} 
inducing or suppressing emotions in order to produce in others the feelings of safety, confidence, and well-being. ${ }^{18}$ In addition, Hardt and Negri also include in affective labor waged work that aims at producing affects, but does not require personal contact. Their example would be people working in the entertainment industry $(2000,293)$.

As the forms of affective labor are so varied, it seems clear that the political consequences, power relations, and forms of exploitation are also vastly different in the disparate cases. It is my contention that effective feminist politics can only be built on the theoretical recognition of these differences and not on their eradication. I want to raise three different sets of political issues that I claim are at stake in our analyses of affective labor and outline three corresponding feminist political projects: the demand for better work, the demand for the moral limits of the market, and the demand for the recognition of the specific role of women's reproductive labor in capitalism. All of these feminist political projects build in different ways on affective labor. However, they require that we are able to make both theoretical and normative distinctions between different forms of affective labor and that we recognize the theoretical and political specificity of each of these forms.

My first political project can be understood simply as a variant of traditional labor struggles. When Hardt and Negri discuss affective labor in Empire, they note in passing: "when affective production becomes part of waged labor it can be experienced as extremely alienating: I am selling my ability to make human relationships, something extremely intimate, at the command of the client and the boss" $(2000,111)$. From the perspective of feminist politics, this is a key aspect of affective labor, however. When the work requires the worker to supply not only intellectual and manual skills but also emotional capacities, something very different is drawn into the labor process.

Arlie Hochschild's groundbreaking sociological study of flight attendants, The Managed Heart ([1979] 2012), introduced the concept of emotional labor into feminist theoretical debates and made the powerful argument that emotional laborers in the service sector do not just sell their ability to create human relationships. They are selling emotions that require drawing resources from a source of the self that we usually honor as deep and integral to our individuality. She asks what happens to the worker and to the way she relates to her feelings when the rules about how to feel, and how to express feelings, are set by the management and when private

\footnotetext{
${ }^{18}$ See Hochschild ([1979] 2012, 7).
} 
capacities for empathy and warmth are put to corporate use ([1979] 2012, 89). In the flight attendant's work, for example, smiling is separated from its usual function, which is to express a personal feeling, and attached to another one - expressing a company feeling (127). Hochschild documents the problems that flight attendants experience when what is usually a private management of feeling is transformed into emotional labor for a wage. Their work experience includes the difficult task of managing the estrangement between the private self and the public feeling or between self and display (131).

Hochschild thus exposes an unseen and undervalued aspect of waged work most often performed by women and strongly associated with femininity. The upshot of her analysis for feminist politics is fairly obvious but nevertheless significant. Feminist political projects attempting to reconfigure the role of work must make affective labor visible and demand political recognition and respect for it. Care work, mostly done by women, continues to be very badly paid compared to industrial blue-collar labor most often performed by men, for example, yet care workers do much more than just perform menial tasks. By understanding the psychological costs of different forms of affective labor, we can try to mitigate or remove them by adequate compensation and by increasing the workers' control over the conditions of their work. ${ }^{19}$

However, while labor struggles aiming to achieve political recognition for affective labor are undoubtedly important, the more fundamental problem concerns the question of how certain affective services can be properly compensated at all. How do we monetize affective labor? The positive affects that affective labor produces are curious products in the sense that their sale radially alters their meaning and value. If I pay for friendship or love, it seems legitimate to question whether it really is friendship or love any longer. To formulate the problem in economic terms, the affects that affective labor produces are positive externalities and their value cannot therefore be easily monetized.

Hardt and Negri take up the issue of externalities in Commonwealth and note how externalities present a persistent problem for capitalist economic theory $(2009,281)$. They argue that the important and growing role of externalities allows us to rethink some of the standard assumptions of political economy, however, and this opens up an important avenue for resistance (155). Rather than subsuming and organizing all labor in an attempt to exploit it, in the new informational economy capital increasingly merely seeks to capture and expropriate autonomously produced com-

${ }^{19}$ See Hochschild ([1979] 2012, 187). 
mon wealth such as knowledges, languages, codes, information, social relationships, and affects. This is possible because immaterial labor always involves social interaction and cooperation, but this cooperative aspect is not imposed or organized from the outside by capital, as it was in the case of industrial labor, for example. Instead, such cooperation is completely immanent to the immaterial laboring activity itself, providing "the potential for a kind of spontaneous and elementary communism" (2000, 294). Hence, affective labor produces spontaneously positive externalities such as social networks, attachments, and passions that capital needs and seeks to appropriate. These positive externalities could also, potentially, form the bases for alternative modes of production and forms of life.

Hardt and Negri are undoubtedly right in insisting that the exploitation of immaterial labor assumes new forms today such as the buying of patents and intellectual property rights. In the case of affective labor, however, the principal way that capital still attempts to expropriate it is by organizing it from the outside and transforming it into low-wage, productive labor. The increasing marketization of care work is a paradigmatic example of this trend. Care workers are predominantly performing affective services today as low-waged laborers, not as innovators and cognitive capitalists. Their work is poorly paid and of low status, and it is disproportionately performed by women from subordinated racial-ethnic minorities in most Western countries. The current "crisis of care," the lack of sufficient numbers of qualified care workers who actually care, and the failed attempts to introduce nursing robots in elder-care facilities, for example, must be understood as symptomatic of this drive to commodify affective labor and of the serious difficulties in doing so. My point is that, in order to provide a critical, feminist analysis of this development, we must make the theoretical distinction between unproductive and productive, or uncommodified and commodified, affective labor, in order to be able to pose the question of what are the political consequences of the former increasingly becoming the latter.

This brings me to my second set of political issues. We must not only ask the economic question of how certain affective services can be appropriately compensated for; we also have to ask the ethical question of whether they should be for sale in the first place. We must consider the argument that many affective services cannot be compensated with money at all, not just for the economic reason that they are externalities but for ethical reasons. Markets allocate goods and services, but they also importantly express and promote certain meanings, values, and attitudes toward the goods and services that are exchanged. Sex work and commercial surrogate pregnancy are illuminative examples. The legal restrictions that govern 
them vary widely between different countries and reflect the moral difficulties surrounding their sale. ${ }^{20}$

Flight attendants suffer from problems of estrangement, but when commodified affective labor is also commodified reproductive labor, the issue becomes much more troubling. Commercialized surrogate pregnancy is a fast-growing aspect of medical tourism today, and India has become a transnational hub for such reproductive tourism. American and European infertile couples wishing to have a child are increasingly traveling there because commercial surrogacy is legal, virtually unregulated, and readily available for a fraction of what it costs in the United States. ${ }^{21}$ Wealthy and middle-class Western couples can engage a gestational surrogate to carry and give birth to their genetic child under highly monitored and regulated conditions in a private clinic. ${ }^{22}$

The experiences of the Indian surrogates who rent their wombs to foreigners obviously vary vastly and are perhaps not adequately captured by the Marxist term “alienation." The idea of alienation does, however, point toward a dimension of critique that is not just concerned with exploitation and economic equity but with the moral meaning and value of different laboring practices. The Indian surrogates are invariably very poor and, unsurprisingly, when interviewed, the reason they give for engaging in surrogacy is money. They also describe the emotional strategies, as well as the overwhelming difficulties, in trying to detach themselves from the baby they are carrying or even from their own pregnant bodies. ${ }^{23}$

Weeks' appropriation of the autonomist Marxist theory means refusing any recourse to a critique of alienation. She criticizes Hochschild's work on emotional labor for being outdated to the extent that Hochschild still relies on the notions of authenticity and an essential self. According to Weeks, Hochshild's argument is animated by an ideal of a separate world of emotional contact with one's "true" self - the possibility of which it simultaneously disavows in acknowledging the social construction of emotions

${ }^{20}$ While commercial surrogate pregnancy is legal in the United States, for example, it is a criminal act in Canada as well as in most European countries. See, e.g., Panitch $(2013,276)$.

${ }^{21}$ No laws regulate surrogacy in India, but the Ministry of Health and Family Welfare has established a set of guidelines. Commercial surrogacy costs between $\$ 40,000$ and $\$ 150,000$ in the United States and between \$12,000 and \$25,000 in India. Contract pregnancies have become a $\$ 445$ million business in India, and the Indian Council of Medical Research expects profits to reach $\$ 6$ billion in the coming years. See Bailey $(2011,717-18)$.

${ }^{22}$ A gestational surrogate is someone who is implanted with an embryo created by the egg and sperm of the contracting parents, or the sperm of the contracting father and an egg donated or purchased from another woman. A genetic surrogate is someone who contributes an egg that is fertilized with the sperm of the contracting father and who then gestates the fetus.

${ }^{23}$ See, e.g., Hochschild (2013). 
(Weeks 2007, 244). Weeks also criticizes traditional Marxist theorists of alienation for "a tendency toward nostalgia for an earlier time" in which small-scale production dominated $(2011,87)$. She sees their critique of alienation as "a romanticization of craft production" informing their visions of an alternative to capitalism $(87) .{ }^{24}$

It is my contention that Weeks overlooks something crucial here by glossing over the distinction between productive and reproductive labor, however. It is a significantly different claim to argue that we should all build our own furniture in our garden sheds than it is to argue that we should "make" our own babies instead of outsourcing pregnancy to India. Whether we want to use the concept of alienation or not, there nevertheless seems to be a range of human labor, specifically affective labor, that for ethical reasons lends itself poorly to commodification.

As Cinzia Arruzza (2014) has argued, capitalist modernity can be understood as a historical process that has resulted in the constitution of the individual as a subject of unique, irreducible, and essentially private emotions. On the one hand, as modern, capitalist subjects, we are thus interpellated to recognize our "true" emotions as expressions of our inner and most authentic self. On the other hand, these emotions are detached from us and constructed as interchangeable and measurable things that can be commodified - exchanged in the market and sold as skills. The alienation experienced by people providing commodified affective labor lies precisely in this contradiction. It should therefore not be conceptualized as a contradiction between naturalness and artificiality, authenticity and inauthenticity, but rather as a contradiction between two different forms of experience that are both socially mediated and that both form an essential aspect of what it means to live in capitalist society today.

Hence, while this insight implies that we should not seek resources for resistance in romantic ideas of authenticity and naturalness, neither should we conclude that the forms of social mediation in the management of our affects are fundamentally the same in all spheres of society. The corporate management of workers' emotions has specific and problematic aspects when compared to the way that all people sometimes hide their "true" feelings in social contexts for various reasons. The disconnection between the lived emotions and their outward display has to be sustained for significant periods of time, for example, and takes the form of a double dis-

${ }^{24}$ Weeks $(2011,90)$ notes approvingly how Negri, for example, expresses no interest in the problematic of alienation as a discourse of interiority concerned with the loss and restoration of an essential human nature. There is, by Negri's reading of the Grundrisse, no concept of work to restore or to liberate. See e.g., Negri $(1991,10)$. 
connection in the sense that the form that the "false" outward display takes is determined by the employer.

In other words, feminist resistance to the commodification of certain forms of affective labor is not a matter of defending private authenticity against social reification but rather an attempt to mediate, shape, and manage our affects through freer and less exploitative social relations. Thus, such a political project does not have to rely on the idea of a true self or true love. It does not imply that we cannot challenge those contemporary discourses that naturalize and idealize certain forms of the family. Instead feminism could be viewed as a political project demanding restrictions on the commodification of our everyday life in order to create new or different forms of the subject, forms of love, and relationships. ${ }^{25}$

It could be objected here that while it might be difficult or even absurd to monetize affective labor, this does not mean that it is not actually happening. Feminist politics can only be rooted in a conceptual grasp of contemporary reality, not in its disavowal and sanctimonious moral condemnation. However, neither can feminist politics amount to merely watching on the sidelines as these processes of commodification unfold. Rather than suggesting that feminists should simply condemn the morality of capitalist markets en toto, I believe that feminism should form a bold and vocal strand in the public, political, and moral debate on the desirable limits of the markets - for example, in the ongoing debates on sex work and surrogate pregnancy - debates that our societies acutely need today.

Engaging in such a moral and political debate is unfortunately beyond the scope of this article, however. ${ }^{26}$ Rather, my question here is what kinds of theoretical tools feminists need in order to effectively engage in it. What such a feminist debate requires is the ability to draw a theoretical distinction between commodified and noncommodified affective services. In other words, what is essential is not the distinction between productive and unproductive labor in the moralizing sense of whether a form of labor contributes to social production or not. What is essential is whether a service is brought within the domain of the markets or whether its appropriate place is considered to be outside of that domain. This has direct consequences for pressing political questions concerning equal access and

${ }^{25}$ See, e.g., Foucault (1984).

${ }^{26}$ Philosophers who argue for the need to establish moral limits to the markets usually base their argument on the idea that certain items should remain free of market evaluation either because their sale distorts their value or undermines the dignity of the vendor. Many arguments also consider the way marketization increases inequality and the possibility of coercion. Market relations should only be considered free when the background conditions under which people buy and sell are fair: in other words, when they are not coerced into selling by dire economic necessity, for example. See, e.g., Radin (1996) and Sandel (2012). 
democratic political control over such services, but it is also fundamental for the assignment of their moral meaning and value. In other words, from the perspective of feminist politics, it is counterproductive to argue that all affective labor should be understood as productive labor. Feminist politics should, on the contrary, resist the prospect of that ever happening.

\section{Reproductive labor}

While my first two sets of political issues challenge the viability of eradicating the distinction between productive and unproductive labor, my third set challenges the eradication of the distinction between material production and social reproduction. From the perspective of feminist politics it is important not to lose sight of the fact that affective labor, when it is understood as reproductive labor, not only produces positive externalities such as socialization, education, and interpersonal values of belonging, but it produces, essentially, human beings. To put the point bluntly, babies are not positive externalities of biopolitical production that add value to commodities; from an economic perspective they have to be recognized as a necessary condition for any form of continuing production.

As feminist theorists working in the social reproduction framework have argued, the production and reproduction of labor power is an essential condition undergirding the dynamic of the capitalist system, making it possible for capitalism to reproduce itself. According to them, the sociomaterial roots of women's oppression under capitalism can only be explained by "the structural relationship of the household to the reproduction of capital: capital and the state need to be able to regulate their biological capacity to produce the next generation of laborers so that labor-power is available for exploitation" (Ferguson and McNally 2014, $\mathrm{xxv}$ ). In other words, social reproduction in the form of producing and socializing the next generation of workers is a necessary condition for the existence of wage laborers and the functioning of the capitalist system. Hardt and Negri are undoubtedly right in insisting that capitalism relies on cooperation at the point of production, but at the point of reproduction, on the contrary, it relies on isolation and atomization, in the form of an individualized nuclear family. ${ }^{27}$

Weeks criticizes traditional Marxist-feminist accounts for relying on the gendered distinction between reproduction and production and thereby settling for a too-narrow concept of affective labor. But feminist critique has to be able to identify and theorize the specific role of affective labor in

${ }^{27}$ See, e.g., Dalla Costa and James (1973). 
capitalism in the narrow sense of women's reproductive labor: currently only women get pregnant and give birth to children. Weeks is clearly concerned that if contemporary feminist politics focuses on issues that are seen to be affecting only certain women, such as reproduction and child care, this inevitably means falling back on exclusionary forms of identity politics. She advocates a political demand for an unconditional basic income, a social wage or a citizen's wage, and argues that it is precisely the gender neutrality of the demand for basic income that should be counted as its feminist strength because this means that its benefits are not exclusive to any particular group of women. The demand can speak to the concerns of a number of differently situated subjects, including a much broader constituency of women that those who are directly involved in social reproduction $(2011,149) .{ }^{28}$

However, to see reproduction as an issue that concerns only a particular group of women means accepting the capitalist framework, which views it as a consumer choice: the decision to have a child is another costly preference. Weeks herself convincingly exposes and criticizes such an individualizing framework by writing, for example, that "the family and its ideology help to obscure the cost of productive labor by privatizing, feminizing, and naturalizing much of the work involved in its reproduction" $(2011,143)$. Feminist politics must not only expose and criticize the structural relationships between capitalism and the heterosexual nuclear family, however. We must also proceed from this theoretical insight to the radical political acknowledgment that the social organization of reproductive labor is not an issue that can be limited to the interests of any particular group of people. It has to be understood as a political issue that directly concerns the future and the economic productivity of society as a whole.

A gendered division of labor that assumes that women bear responsibility for reproductive labor in the private realm is admittedly not the only imaginable way to reproduce labor power-we could imagine futuristic baby factories, the preliminary outlines of which we are perhaps already

\footnotetext{
28 The feminist critics of basic income have voiced the concern that instead of promoting gender equality, a basic income would instead reinforce the existing sexual division of labor by giving women an even greater incentive to undertake more unpaid caring work in the household. Even the feminist advocates of basic income generally admit that an unconditional and universal basic income alone will not guarantee that men would scale back time spent in paid employment, or that if they did, that they would thereby increase the time spent in care work. Women's position in the labor market combined with deeply rooted beliefs about the appropriate tasks of men and women make this seem, if not unlikely, at least far from inevitable. On feminist assessments of basic income, see, e.g., Pateman (2004) and Zelleke (2011).
} 
seeing in India, or we could export, and in fact have exported, slaves from foreign countries, for example. However, most people would argue, for a variety of moral, political, and economic reasons, that the labor required for human reproduction cannot be completely commodified and brought into the sphere of market transactions. ${ }^{29}$ That is in fact why we have to identify two different and opposing tendencies in capitalism concerning reproductive labor. On the one hand, there is the constant drive to extend the reach of the markets, to commodify the private realm, and to turn women into wage laborers. On the other hand, there is the necessity to uphold a sexist division of labor and to rely on women's unpaid reproductive labor in the private sphere, as it has proven indispensable for a functioning modern capitalist economy.

The problem is that this way of organizing social reproduction makes economic gender equality in capitalist society a structural impossibility. To achieve economic gender equality in this system of production would require a much more radical restructuring of society and economy than even most feminists are willing to consider. Most feminists obviously recognize the necessity of women's reproductive and care work and insist on some kind of redistributive measures in order to compensate for it, such as the Scandinavian model. According to its advocates, gender equality would require free or subsidized provision of early childhood education and care, limits on the number of hours in the working week, the availability of partial employment, and generous family leave policies that would provide incentives for equal use by both fathers and mothers. ${ }^{30}$

However, in an economic system in which resources are primarily distributed to individuals according to their ability to compete in the economic game-as opposed to their need or their right to these resources, for example - those women who carry the burden of reproduction cannot participate in this game on equal terms. As long as the fact remains that it is only the mother's body that has to go through the extra burden of pregnancy and childbirth, and that only the mother has to take at least some time off from paid employment in order to do this, women's reproductive labor can only ever be a handicap in the economic game.

In political conditions with sufficient feminist pressure, society can be made to compensate women for this labor with various political and so-

${ }^{29}$ Karl Pollanyi (2001) famously conceived of labor, land, and money as fictitious commodities. He saw capitalist crises as the result of treating these fundamental bases of social life as if they were ordinary commodities. Subjecting them to market exchanges could only result in the destruction of the environment as well as communities. For a feminist appropriation of Pollanyi's theory, see Fraser (2013).

${ }^{30}$ See, e.g., Bowman and Cole (2009). 
cial measures external to the market, but it can never completely remove this handicap. This implies that gender equality in capitalism would in fact require the very opposite of the Scandinavian model. For childbearing women to be able to participate in the economic game on equal terms would require that their reproductive labor be completely commodified, down to its most intimate aspects, and its price freely determined in the market in the same way as the price of other commodities.

I am obviously not advocating a free market for babies here. I am merely trying to demonstrate a fundamental point of tension between capitalism and gender equality. If we do not want to settle for an approximation of gender equality, feminist politics would have to engage in a much more profound critique of capitalism than mere demands for affordable nurseries and better paid work. The third feminist political project that I am outlining is thus considerably more radical than the first two. In order to seriously address the role of reproduction in capitalism, feminist politics would have to return to some of the most extreme strands of radical feminism and Marxist feminism and demand a complete reorganization not only of our current modes of social reproduction but also of our current modes of economic production. ${ }^{31}$ Feminism would have to make central again the early Marxist-feminist insight that the intertwinement of capitalism and sexism is not just a contingent configuration. Instead, it is indispensable and socially necessary for contemporary capitalism, for at least two reasons related specifically to reproduction. Women must carry the burden of reproduction in a disproportionate manner due to their biological capacity to get pregnant and give birth, and, second, the reproductive labor that they currently perform cannot be completely commodified and brought into the realm of market transactions. While the feminist movement has had some success in socializing and ungendering reproduction, the biggest change by far in the conditions under which we reproduce has been the commodification and globalization of care work. The gendered nature of reproductive labor has therefore not changed at all. Reproductive labor has only been redistributed to new female subjects - to poor, immigrant, and third-world women. ${ }^{32}$

${ }^{31}$ The wages for housework campaign in the 1970s, for example, was an international feminist mobilization that attempted to force the state to recognize that domestic work was work, an activity that should be remunerated as it contributed to the production of the labor force and produced capital. As Federici (2012, 8-9) describes the movement, it was revolutionary at the time because it recognized that capitalism required unwaged reproductive labor in order to contain the cost of labor power. The idea was that a successful campaign draining the source of this unpaid labor would break the process of capitalist accumulation.

${ }^{32}$ See, e.g., Ehrenreich and Hochschild (2002). 
To conclude, the notion of affective labor foregrounds a set of pressing issues that are at the heart of feminist theory and politics today. It picks out a gendered form of labor that is central for understanding capitalism. It holds subversive potential for anticapitalist critiques and feminist politics. However, by treating very different kinds of experiences, activities, and services as the same, the notion ends up obscuring the forms of oppression and exploitation at stake and leaves feminists unable to formulate concrete proposals for forms of resistance against them. Affective labor should be a pivotal notion for feminism. But it therefore deserves a more careful theoretical analysis.

Department of Philosophy, History, Culture, and Art Studies University of Helsinki

\section{References}

Arruzza, Cinzia. 2014. “The Capitalism of Affects.” Public Seminar 1(2). http:// www.publicseminar.org/2014/08/the-capitalism-of-affects.

Bailey, Alison. 2011. "Reconceiving Surrogacy: Toward a Reproductive Justice Account of Indian Surrogacy." Hypatia 26(4):716-41.

Bowman, John R., and Alyson M. Cole. 2009. "Do Working Mothers Oppress Other Women? The Swedish 'Maid Debate' and the Welfare State Politics of Gender Equality." Signs: Journal of Women in Culture and Society 35(1):157-84.

Dalla Costa, Mariarosa, and Selma James. 1973. The Power of Women and the Subversion of the Community. Bristol: Falling Wall.

Ehrenreich, Barbara, and Arlie Russell Hochschild. 2002. Global Woman: Nannies, Maids, and Sex Workers in the New Economy. New York: Metropolitan.

Eisenstein, Hester. 2009. Feminism Seduced: How Global Elites Use Women's Labor and Ideas to Exploit the World. Boulder, CO: Paradigm.

Engels, Friedrich. (1884) 1972. The Origin of the Family, Private Property and the State. Edited by Eleanor Burke Leacock. New York: International.

Federici, Silvia. 2012. Revolution at Point Zero: Housework, Reproduction, and Feminist Struggle. Oakland, CA: PM.

Ferguson, Susan, and David McNally. 2014. "Capital, Labour-Power, and GenderRelations: Introduction to the Historical Materialism Edition of Marxism and the Oppression of Women." In Marxism and the Oppression of Women: Toward a Unitary Theory, ed. Lise Vogel, xvii-xl. New York: Haymarket.

Foucault, Michel. 1984. "Sex, Power, and the Politics of Identity." In Ethics, Subjectivity and Truth: Essential Works of Foucault 1954-1984, ed. Paul Rabinow, 163-73. New York: New Press.

- 2003. Society Must Be Defended: Lectures at the College de France 19751976. Edited by Mauro Bertani and Alessandro Fontana. Harmondsworth: Allen Lane, Penguin. 
Fraser, Nancy. 2013. Fortunes of Feminism: From State-Managed Capitalism to Neoliberal Crisis. London: Verso.

Hardt, Michael, and Antonio Negri. 2000. Empire. Cambridge, MA: Harvard University Press.

- 2004. Multitude: War and Democracy in the Age of Empire. London: Penguin.

- 2009. Commonwealth. Cambridge, MA: Belknap Press of Harvard University Press.

Hochschild, Arlie Russell. (1979) 2012. The Managed Heart: Commercialization of Human Feeling. Berkeley: University of California Press.

- 2013. The Outsourced Self: What Happens When We Pay Others to Live Our Lives for Us. London: Picador.

Honneth, Axel, and Martin Hartmann. 2006. "Paradoxes of Capitalism." Constellations 13(1):41-58.

Lukács, Georg. 1971. History and Class Consciousness: Studies in Marxist Dialectics. Translated by Rodney Livingstone. Cambridge, MA: MIT Press.

Marx, Karl. (1867) 1976. Capital: A Critique of Political Economy, Vol. I. Translated by Ben Fowkes. London: Penguin.

Mies, Maria 1998. Patriarchy and Accumulation on a World Scale: Women in the International Division of Labour. London: Zed.

Mitchell, Juliet. 1971. Women's Estate. Baltimore: Penguin.

Morini, Cristina. 2007. "The Feminization of Labour in Cognitive Capitalism." Feminist Review, no. 87: 40-59.

Negri, Antonio. 1991. Marx beyond Marx: Lessons on the Grundrisse. Translated by Harry Cleaver, Michael Ryan, and Maurzio Viano. Brooklyn, NY: Autonomedia.

Panitch, Vida. 2013. "Surrogate Tourism and Reproductive Rights." Hypatia 28(2):274-89.

Pateman, Carole. 2004. "Democratizing Citizenship: Some Advantages of a Basic Income." Politics \& Society 32(1):89-105.

Pollanyi, Karl. 2001. The Great Transformation: The Political and Economic Origins of Our Time. Boston: Beacon.

Quinby, Lee. 2004. "Taking the Millennialist Pulse of Empire's Multitude: A Genealogical Feminist Diagnosis." In Empire's New Clothes: Reading Hardt and Negri, ed. Paul A. Passavant and Jodi Dean, 231-51. London: Routledge.

Radin, Margaret Jane. 1996. Contested Commodities: The Trouble with Trade in Sex, Children, Body Parts, and Other Things. Cambridge, MA: Harvard University Press.

Sandel, Michael. 2012. What Money Can't Buy: The Moral Limits of Markets. New York: Farrar, Straus \& Giroux.

Tronti, Mario. 1966. Operai e capitale [Labor and capital]. Torino: Einaudi.

Vogel, Lise. 1983. Marxism and the Oppression of Women: Toward a Unitary Theory. New Brunswick, NJ: Rutgers University Press. 
Weeks, Kathi. 2007. "Life Within and Against Work: Affective Labor, Feminist Critique, and Post-Fordist Politics." Ephemera: Theory \& Politics in Organization $7(1): 233-49$.

- 2011. The Problem with Work. Feminism, Marxism, Antiwork Politics, and Postwork Imaginaries. Durham, NC: Duke University Press.

Zelleke, Almaz. 2011. Feminist Political Theory and the Argument for an Unconditional Basic Income.” Policy \& Politics 39(1):27-42. 